\title{
\#FeesMustFall and the campaign for universal health coverage
}

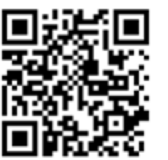

The recent \#FeesMustFall protests by students seeking better access to tertiary education remind us how politically and socially explosive inequitable access to social services can be. The protests have effectively highlighted government underfunding of tertiary education and surfaced dissatisfaction with persistent income and service disparities more generally.

As we approach the second Universal Health Coverage Day on 12 December, and with the reportedly imminent release of the National Health Insurance White Paper in South Africa (SA), we need to reflect as a society on our commitment to equitable access to good-quality health services.

On taking office, President Mandela launched his flagship project for free health services for pregnant women and children aged under 5 . This was followed by free primary healthcare services. Mandela recognised not only that access to healthcare was an essential human right, but also that it was an important contribution to the nation-building project, along with other elements of the Reconstruction and Development Programme (RDP).

Yet, in 2015, as is the case with higher education, 'the missing middle' of the SA population finds itself with impediments to access: it is insufficiently poor to be exempted from paying user fees for public hospital services, but often too poor to afford them. Many of those eligible for 'free' healthcare face insurmountable indirect costs, especially for transport. ${ }^{[1]}$ For many who belong to medical schemes, monthly contributions and associated out-of-pocket payments consume an unsustainable proportion of their incomes. ${ }^{[2]}$

If we examine trends in government expenditure on healthcare, the first decade of the post-apartheid era saw a surprising decline in per capita government expenditure on health, even as the per capita gross domestic product (GDP) increased (Fig. 1). The share of the government budget allocated to health also declined and stagnated at around $11.7 \%$ for much of this decade, never returning to its 1996 high of $14.1 \%$ (Fig. 2). This occurred at a time when the Department of Health was struggling to remedy the severe backlogs in healthcare infrastructure and human resource production that characterised the apartheid era, and as the HIV/AIDS epidemic escalated into the biggest in the world. Over this same period, the education sector's percentage share of government expenditure declined even more precipitously. Strangest of all, these downward trends occurred as total government revenue doubled in real terms. ${ }^{[3]}$

In recent months, government has committed to increasing funding for higher education in response to the \#FeesMustFall protests. Slowly increasing public per capita health expenditure in recent years (Fig. 1), and the proposed National Health Insurance, suggest that the debilitating consequences of the 'lost decade' in healthcare have rekindled a commitment to universal health coverage.

However, is it feasible in the current context to improve public funding for the health and education sectors? Would gains that have been made in other sectors addressing the social determinants of health, such as the social grants programme, housing and water, not be compromised? The lessons of the post-apartheid era suggest that a shift in fiscal policy is required.

Economic growth for many of the early years following the election of the first democratic government provided a window of opportunity for improved tax collection and transformation of government services. However, in 1996 the launch of a new macroeconomic policy, the Growth, Employment and Redistribution strategy (GEAR), reined in the public expenditure anticipated under the earlier RDP. It also required reducing the budget deficit and rapid servicing of debt (which peaked at $21.2 \%$ of total government expenditure in 1998/99) (Fig. 2). This placed a squeeze on the 'fiscal space' for health and education. This was followed by increasing allocations to the 'economic affairs' sector, which exceeded the health sector's share by $2006 / 07$.

A key element of GEAR was a commitment to 'maintaining a ratio of tax to GDP of about 25 per cent. ${ }^{[4]}$ The transformation of the South African Revenue Service led to a dramatic increase in real tax revenue, and so reductions in personal income and corporate tax rates assisted in maintaining the tax-to-GDP ratio, which proved popular with the public. According to Treasury's annual budget reviews, the rate for the highest income tax bracket dropped from $45 \%$ to $40 \%$ between 1996 and 2008, and from $35 \%$ to $28 \%$ for corporate income tax rates.

If $\mathrm{SA}$ is to achieve equitable access to the full range of social services, not only at the 'basic level' (such as basic education and primary healthcare services) but also at higher levels (higher education and all levels of referral hospitals), the fiscal policy limit on government revenue as a percentage of GDP needs to be lifted. The current limit is well below the average in other middle-income countries, of over 32\% in Latin America and 37\% in Central and Eastern Europe $^{[5]}$ (the average for Organisation for Economic Cooperation and Development (OECD) countries in 2013 was $34 \%$, according to the official OECD statistics website https://stats.oecd.org/Index. aspx? DataSetCode=REV). Increasing the limit is critical, given massive income inequality in SA. As the Economists' Declaration in a recent issue of The Lancet states, investing in health systems will 'foster more cohesive societies and productive economies. ${ }^{\text {'[] }}$

It will be important to focus on progressive revenue sources, including taxing the wealthiest more effectively, as well as multinational corporations. This would be in line with the global agreement reached for funding the sustainable development goals, which concluded that:

'We recognize that significant additional domestic public resources ... will be critical to realizing sustainable development and achieving the sustainable development goals. ... We will redouble efforts to substantially reduce illicit financial flows by 2030, with a view to eventually eliminating them, including by combating tax evasion and corruption through strengthened national regulation and increased international cooperation. ... We will make sure that all companies, including multinationals, pay taxes to the Governments of countries where economic activity occurs and value is created, in accordance with national and international laws and policies. ${ }^{[7]}$

New government revenue will not easily flow to the health sector, however. National and provincial health leaders have generally battled to make the case for health in national and provincial decision-making bodies. This has been a function of weak health leaders at some moments in history, combined with insufficient technical and analytical capacity to support bids, especially with respect to the costing of programmes. ${ }^{[3]}$

Also, as among the most powerful players influencing budget decisions, the Minister of Finance and Treasury have at times resisted requests for increased funding from the Department of Health, especially when they distrusted the public health sector's ability to deliver. ${ }^{[3]}$

These are some of the political and administrative challenges that characterise the struggle policy-makers and health advocates 
face on a daily basis to protect spending on healthcare. These challenges will intensify with the struggle to implement National Health Insurance, which will bring a host of other challenges, not least resistance from stakeholders benefiting from the current status quo.

To preserve the impetus towards universal health coverage, the Minister of Health and others need to engage with debates within Cabinet and Treasury on appropriate macroeconomic and fiscal policy choices. The Department of Health will strengthen these arguments, and win the trust of colleagues from Cabinet and Treasury, if it is able to demonstrate achievements in service delivery and combat corruption.

Acknowledgments. This work is based on research supported by the RESYST (Resilient and Responsive Health Systems) research consortium funded by UKaid from the Department of International Development. DM is supported by the South African Research Chairs Initiative of the Department of Science and Technology and National Research Foundation (NRF) of South Africa. Any opinion, finding and conclusion or recommendation expressed in this article is that of the authors, and the NRF and UKaid do not accept any liability in this regard.

\section{Jane Doherty}

Independent researcher and part-time lecturer, School of Public Health, Faculty of Health Sciences, University of the Witwatersrand, Johannesburg, South Africa

\section{Di McIntyre}

South African Research Chair in 'Health and Wealth' and Professor, Health Economics Unit, School of Public Health and Family Medicine, University of Cape Town, South Africa

Corresponding author: J Doherty (dohertyj@ telkomsa.net)

1. Cleary S, Birch S, Chimbindi N, Silal S, McIntyre D. Investigating the affordability of key health services in South Africa. Soc Sci Med 2013;80(March):37-46. [http://dx.doi.org/10.1016/j. socscimed.2012.11.035]

2. Ataguba JE, Goudge J. The impact of health insurance on health care utilisation and out-of-pocket payments in South Africa. The Geneva Papers on Risk and Insurance - Issues and Practice 2012;37(4):633-654. [http://dx.doi.org/10.1057/ gpp.2012.35]

3. Doherty J. Increasing Tax Revenue and Its Impact on Financing Health Care in South Africa. London: RESYST (Resilient and

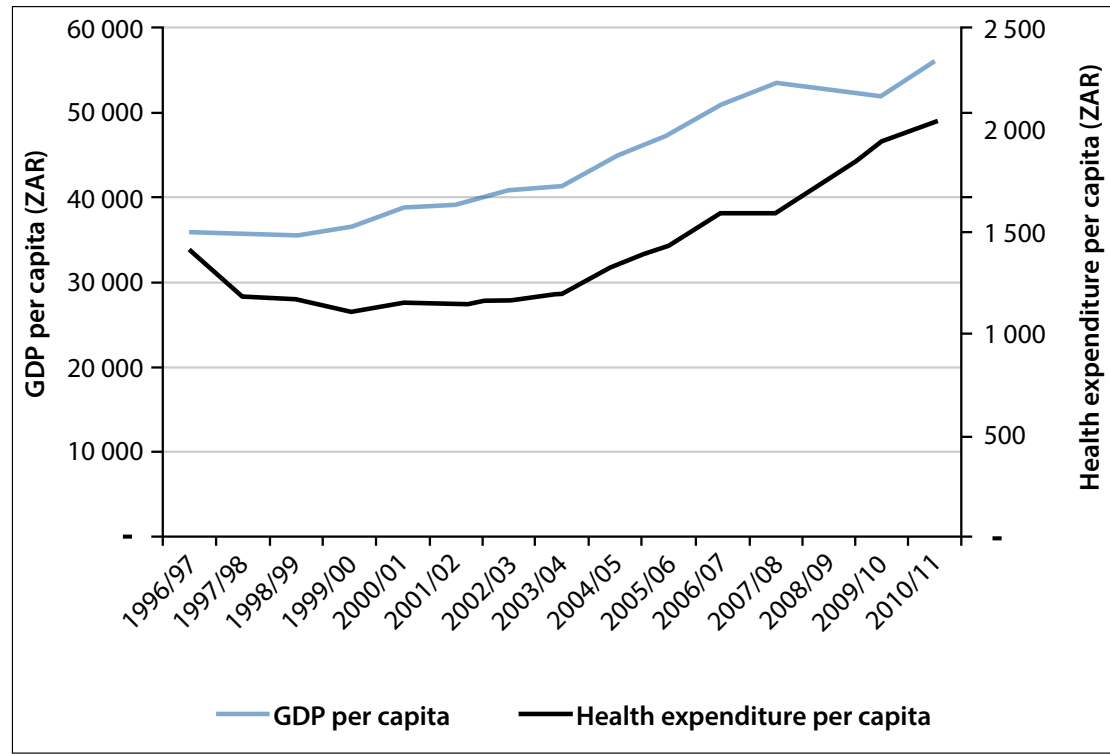

Fig. 1. Public health expenditure in SA fails to keep pace with growth in GDP in the first decade of the post-apartheid era (real terms, 2010 prices). ${ }^{[3]}$

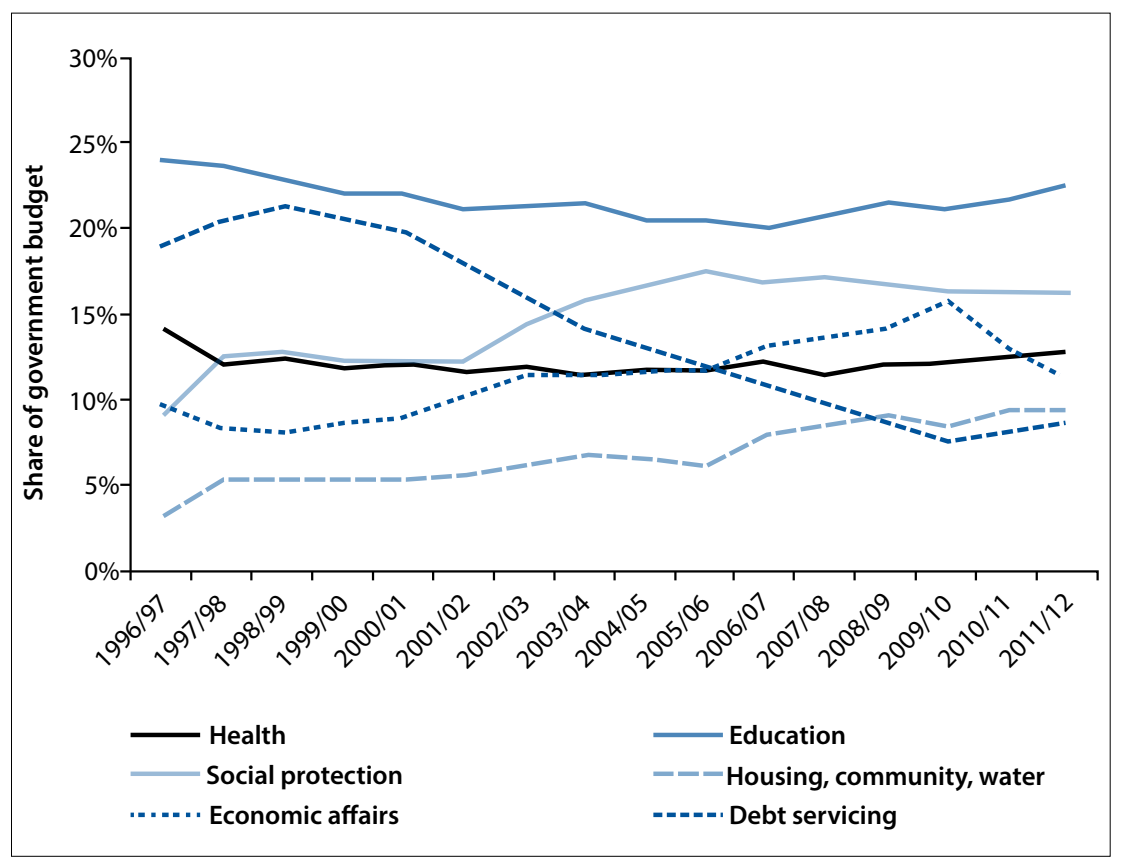

Fig. 2. Health and education in SA receive declining shares of the government budget in the postapartheid era. ${ }^{[3]}$

Responsive Health Systems), London School of Hygiene and Tropical Medicine, 2014. http://resyst.lshtm.ac.uk/sites/resyst. lshtm.ac.uk/files/docs/reseources/Working\%20paper\%206.pd (accessed 8 November 2015).

4. Department of Finance. Growth, Employment and Redistribution: A Macroeconomic Strategy. Pretoria: Department of Finance, 1996:10. http://www.treasury.gov.za/publications/other/ gear/chapters.pdf (accessed 8 November 2015).

5. International Monetary Fund. Fiscal Monitor April 2014 Public Expenditure Reform: Making Difficult Choices. Washington, DC: IMF, 2014. https://www.imforg/external/ pubs/ft/fm/2014/01/pdf/fml401 pdf (accessed \& November (accessed 8 Novembe 2015).
6. Summers LH (on behalf of 267 signatories). Economists declaration on universal health coverage. Lancet 2015. Published online 17 September 2015. [http://dx.doi.org/10.1016/S01406736(15)00242-1]

7. United Nations. Report of the Third International Conference on Financing for Development. New York: United Nations, 2015: clauses 22-23. http://www.un.org/ga/search/view_doc. asp?symbol=A/CONF.227/20 (accessed 8 November 2015).

S Afr Med J 2015;105(12):1014-1015.

DOI:10.7196/SAMJ.2015.v105i12.10339 